\title{
O GIRASSOL E A FORMIGA (DO BELO E MILITANTE)
}

\author{
João Pedro de Sousa Barreto ${ }^{1}$
}

Como as formigas.

Incansáveis na luta

Feitas para a luta

$\mathrm{Na}$ qual se faz a vida.

Como as formigas.

Dispostas em linha,

Dispostas à luta,

Duras tanto quanto.

"Pisa ligeiro! Pisa ligeiro!"

É o seu grito e a sua alma.

Rubro é a cor,

Mesma do sangue,

Quente nas veias,

Motor da coisa toda.

Como o girassol,

Um campo todo deles.

Esperando na luz

do sol de um mundo novo.

$\mathrm{O}$ sol que incita buscar um mundo novo

e lembra,

que o amanhã é sempre um novo dia,

A lutar de novo,

como as formigas.

São os girassóis

\footnotetext{
${ }^{1}$ Graduando do terceiro período do curso de Licenciatura em Educação do Campo - Ciências da Natureza (LEdoC) (UFPI), campi Teresina (PI). E-mail: barretoplay15@gmail.com
} 
que embelezam o campo.

Embelezando a vida.

Mini sóis em brasa

que emitem luz,

lançam-nas aos germens

para um campo novo,

para um mundo novo. 